\title{
Genetic differentiation within and among populations of chestnut (Castanea sativa Mill.) and wild cherry (Prunus avium L.)
}

\author{
N. FRASCARIA ${ }^{1}$, F. SANTI ${ }^{2} \&$ P. H. GOUYON ${ }^{1}$ \\ 'Laboratoire d'Evolution et de Systématique des Végétaux, Bât 362, Université de Paris XI-CNRS (U.R.A. 121), 91405 \\ Orsay; ${ }^{2}+$ Station d'Amélioration des Arbres Forestiers, INRA, Centre de Recherche d'Orleans, F-45160 Ardon, France
}

\begin{abstract}
Isoenzymes were used to examine genetic variability within and among populations of chestnut (Castanea sativa Mill.) and wild cherry (Prunus avium L.). Isoenzymes were sufficiently robust to allow the attribution of chestnut shoots to stumps; other markers were required to confirm the estimations of wild cherry clone sizes. No genetic structure was observed within populations of the two species and no significant departures from Hardy-Weinberg equilibrium were detected for the isoenzymes tested excluding one locus. $F$-statistics and measurements of genetic distances revealed little genetic differentiation among populations of these species. This could be explained by the influence of human activities and the limited number of generations observed for these species since the last glaciation.
\end{abstract}

Keywords: asexual and sexual propagation, Castanea sativa Mill., genetic differentiation, isoenzymes, Prunus avium L.

\section{Introduction}

The genetic differentiation of plant populations using enzymatic markers, which are assumed to represent neutral genes, has been extensively studied during the last 20 years. Hamrick (1989) showed that plants exhibit a generally high level of intrapopulation diversity for enzymatic markers and an interpopulation diversity related to the life-history traits of the species. For example, tree species have a lower interpopulation differentiation than other plants.

However, it is not known whether this low differentiation is also observed for tree species which do not exhibit special adaptation for seed dispersal such as chestnut (Castanea sativa Mill.) and wild cherry (Prunus avium L.) These two species are diploid and monoecious. Pollination is performed by insects for both species and by action of wind for chestnut. Fruits are dispersed by humans and animals. Some vegetative propagation of chestnut may be the result of human activity while suckering occurs naturally for wild cherry. Incompatibility systems can prevent selfpollination in both species (Crane, 1923; Clapper, 1954).

*Correspondence: Nathalie Frascaria.
In the present study, isoenzymatic genetic markers are used to assess the genetic variability of selected populations of chestnut and wild cherry. Our objectives are: (i) to determine the extent of vegetative reproduction and (ii) to estimate the genetic differentiation within and among populations.

\section{Materials and methods}

\section{Sampled populations}

Trees were sampled in 1988 from five pure chestnut stands over a wide geographic area in France (Table 1). To determine the extent of vegetative propagation and within population differentiation, 117 trees were sampled in population $\mathrm{C} 1$.

Between 14 and 81 trees were sampled from four wild cherry populations in 1988 and 1989 (Table 1). Population W1 was an almost pure stand and was systematically sampled using a $30 \times 30 \mathrm{~m}$ grid. The mixed stands of populations W2 and W4 were sampled from four and three clumps, respectively. Trees in population W3 were sampled approximately $50 \mathrm{~m}$ apart from a clump along the edge of the forest.

Growing shoot tips were collected from population W4. Buds were collected from all other chestnut and 
Table 1 Details of the stands investigated. C: chestnut; W: wild cherry. Lat.: latitude; Long.: longitude; S. treat.: stand treatment; s.c.s: simple coppice system; t.f: timber forest; $N$ : number of sampled trees

\begin{tabular}{lllllr}
\hline Stands & Location & Lat. & Long. & S.treat. & $N$ \\
\hline C1 & Angervilliers & $48^{\circ} 35^{\prime} \mathrm{N}$ & $2^{\circ} 30^{\prime} \mathrm{E}$ & s.c.s. & 117 \\
C2 & Saint Caprais & $44^{\circ} 07^{\prime} \mathrm{N}$ & $1^{\circ} 14^{\prime} \mathrm{E}$ & s.c.s. & 15 \\
C3 & Saint Mariens & $45^{\circ} 08^{\prime} \mathrm{N}$ & $0^{\circ} 24^{\prime} \mathrm{E}$ & t.f. & 38 \\
C4 & Alzon & $43^{\circ} 58^{\prime} \mathrm{N}$ & $3^{\circ} 27^{\prime} \mathrm{E}$ & s.c.s. & 36 \\
C5 & Avants Monts & $43^{\circ} 29^{\prime} \mathrm{N}$ & $2^{\circ} 45^{\prime} \mathrm{E}$ & t.f. & 42 \\
W1 & St Andre de l'Eure & $48^{\circ} 55^{\prime} \mathrm{N}$ & $1^{\circ} 17^{\prime} \mathrm{E}$ & t.f. & 61 \\
W2 & Signy l'Abbaye & $49^{\circ} 43^{\prime} \mathrm{N}$ & $4^{\circ} 25^{\prime} \mathrm{E}$ & t.f. & 19 \\
W3 & Gomaringen & $48^{\circ} 26^{\prime} \mathrm{N}$ & $9^{\circ} 08^{\prime} \mathrm{E}$ & t.f. & 14 \\
W4 & Sezanne & $48^{\circ} 41^{\prime} \mathrm{N}$ & $3^{\circ} 43^{\prime} \mathrm{E}$ & t.f. & 81 \\
\hline
\end{tabular}

wild cherry stands, except from population W2 where buds were collected from ramets in a nursery.

\section{Electrophoretic analysis}

Enzyme extractions for chestnut samples were performed according to Frascaria \& Lefranc (1992). Gel buffers were described by Meinzel \& Market (1967) and staining techniques by Harris \& Hopkinson (1976) and Tanksley \& Rick (1980). Three isoenzyme loci were studied, including PGI-1 (E.C.5.3.1.9), IDH-2 (E.C.1.1.1.42) and SDH-1 (E.C.1.1.1.25). The Mendelian inheritance of allozymes variants for these loci was determined by Bonnefoi (1984), Villani et al. (1986) and Fineschi et al. (1990).

Techniques for electrophoresis, the description of isoenzyme variants and the genetic control analysis of wild cherry samples were given in Santi \& Lemoine (1990). Ten polymorphic loci were studied: SDH-1, IDH-1, LAP-1 (E.C.3.4.11.1), MDH-1 and MDH-2 (E.C.1.1.1.37), ACP-1 and ACP-2 (E.C.3.1.3.2), GOT-1 and GOT-2 (E.C.2.6.1.1) and TO (E.C.1.15.1.1.). GOT-1 and LAP-1 loci are closely linked (Santi \& Lemoine, 1991). Three loci, TO (E.C.1.15.1.1), ACP-2, and MDH-2, were only used to aid in the final identification of clones, as their genetic control has not yet been studied successfully.

\section{Statistical analysis}

Isoenzymatic markers were used to detect the possible occurrence of vegetative propagation in population $\mathrm{C} 1$ and all wild cherry populations. Further discrimination of wild cherry populations was achieved using isoenzyme phenotypes of ACP-2, MDH-2 and TO loci, as well as morphological traits (branching habit and grain of the wood, only for population W2).
For population $\mathrm{W} 1$, the probability $(P)$ of observing a group of $n$ or more trees of a given multiple-loci genotype $\mathrm{A}$ without vegetative propagation was computed. Assuming that the parents of the sampled trees were part of a population under Hardy-Weinberg equilibrium and with the same allelic frequencies as the sampled population (total sample size $=N$ ), the probability of the occurrence of one genotype $\underline{A}_{i}(=\underline{a a}$, ab or bb for example) at locus $i$ (SDH-1, IDH-1, LAP-1, MDH-1, ACP-1 and GOT-1) was estimated by the frequency of this genotype in our observed sample. Assuming no linkage disequilibrium, the probability of occurrence of a determined combination A of six genotypes $\underline{A}_{i}$ is:

$P_{\underline{\mathrm{A}}}=\pi_{i=1}^{6} P_{\underline{\mathrm{A}},}$,

$P_{\mathrm{A}_{i}}$ being the probability of the occurrence of genotype A for the locus $i$ (with $i$ as a member of).

In our sample of size 61 , the probability of the occurrence of $k$ individuals with the same genotype $\underline{A}$ is a binomial probability (assuming no distortion in gametic distribution):

$P=\mathrm{C}_{61}^{k}\left(P_{\underline{\mathrm{A}}}\right)^{k}\left(1-P_{\underline{\mathrm{A}}}\right)^{61-k}$,

and the probability that a group of size $n$ or greater occurs with the same genotype $\underline{A}$ is:

$P=\sum_{k=n}^{61} C_{n}^{k}\left(P_{\underline{\mathrm{A}}}\right)^{k}\left(1-P_{\underline{\mathrm{A}}}\right)^{61-k}$.

To determine within-population differentiation, populations $\mathrm{C} 1$ and $\mathrm{W} 1$ were geographically subdivided into sections of equal areas (called subpopulations). Population $\mathrm{C} 1$ was subdivided automatically four ways with a specific computer program (Gouyon, personal communication) into 20 (average size of 5.85 individuals), 12 (9.75 individuals), 11 (10.7 individuals) and 6 (19.5 individuals) subpopulations. Population W1 was subdivided four ways, as the distribution of trees was less homogeneous (without individuals 24 and 17 which were too far away to enter in a group without extending its area), into 7 (average size of 6.9 individuals), 5 (9.6 individuals), 3 (16 individuals) and 2 (24 individuals) subpopulations. Gene frequencies and genotypic data were analysed using the Chi-square test and $F$-statistics (Wright, 1965; Nei, 1977, 1986).

The Gst index, identical to the Fst index when a single locus is considered (Nei, 1973), was used to evaluate genetic differentiation among populations (Nei, 1978). The genetic distance (Nei, 1972) was calculated between pairs of populations.

\section{Results}

Two alleles and three genotypes for each of the three loci studied were recorded in chestnut populations. In 
wild cherry populations, two alleles and three genotypes were observed for the IDH-1, LAP-1, MDH-1 and $\mathrm{SDH}-1$ loci, and three alleles and four genotypes for the ACP-1 and GOT-1 loci. Only one tree (22 in population W1) contained a single allele of GOT -2 . Two phenotypes were recorded for $\mathrm{MDH}-2$ and $\mathrm{TO}$ loci and eight for ACP-2.

\section{Detection of vegetative propagation}

Old chestnut stumps were sometimes so large it was not clear whether they were composed of more than one genotype. Doubtful cases were therefore tested using the three polymorphic loci. By this method, shoots were attributed to the correct stump.
In wild cherry populations, when we examined the distribution of trees within a given group (Figs 1 and 2), the same genotype was found to occur in clusters, presumably representing ramets arising from a single clone through suckering. Furthermore, all trees of a given group were heterozygotes for at least one locus (except for group 96-97 in W4), which excludes local monomorphism as an explanation.

In population W1, 8 groups with identical genotypes were found among 61 trees. Most of them were geographically gathered, which suggested a clonal origin (groups 40-41, 46-47 and 49-50; Fig. 1), but remembering that trees were sampled $30 \mathrm{~m}$ apart, the probability of obtaining through sexual reproduction a homogeneous group of at least size $n(n=$ observed

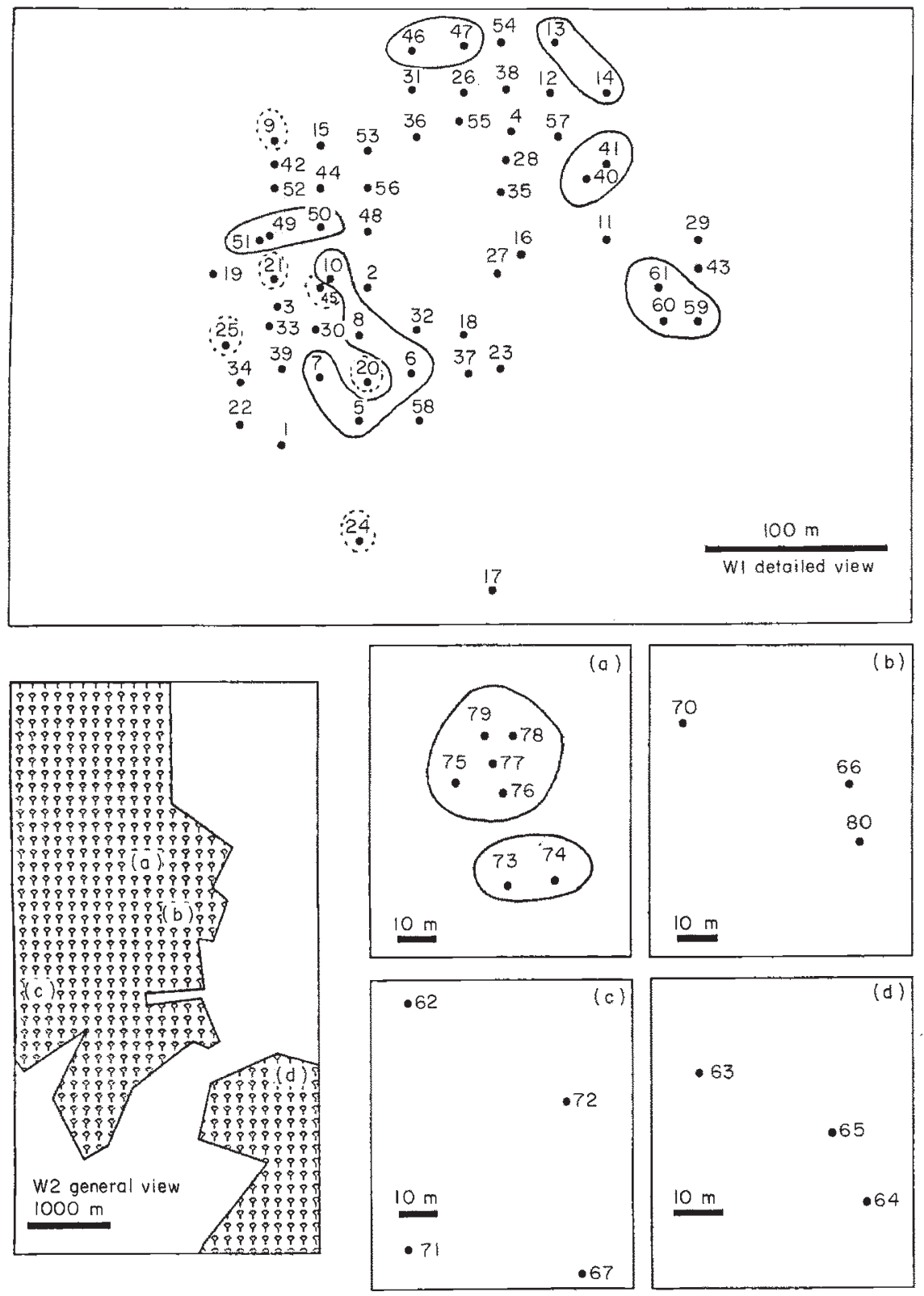

Fig. 1 Spatial distribution of trees in wild cherry populations $\mathrm{W} 1$ and $\mathrm{W} 2$. Numbers refer to individual trees, represented as dots, heavy lines indicate the position and the limits of the supposed clone groups and dotted lines indicate trees which are too widely separated to be included in the supposed clone groups: tree no. 9 from the clone group no. '5-6-7-8-10', tree no. 20 from tree no. 21 , tree no. 24 from tree no. 25 , and tree no. 45 from the clone group no. '46-47'. 
Fig. 2 Spatial distribution of the trees in wild cherry population W4. Numbers refer to individual trees, represented as dots, heavy lines indicate the position and the limits of the supposed clone groups.
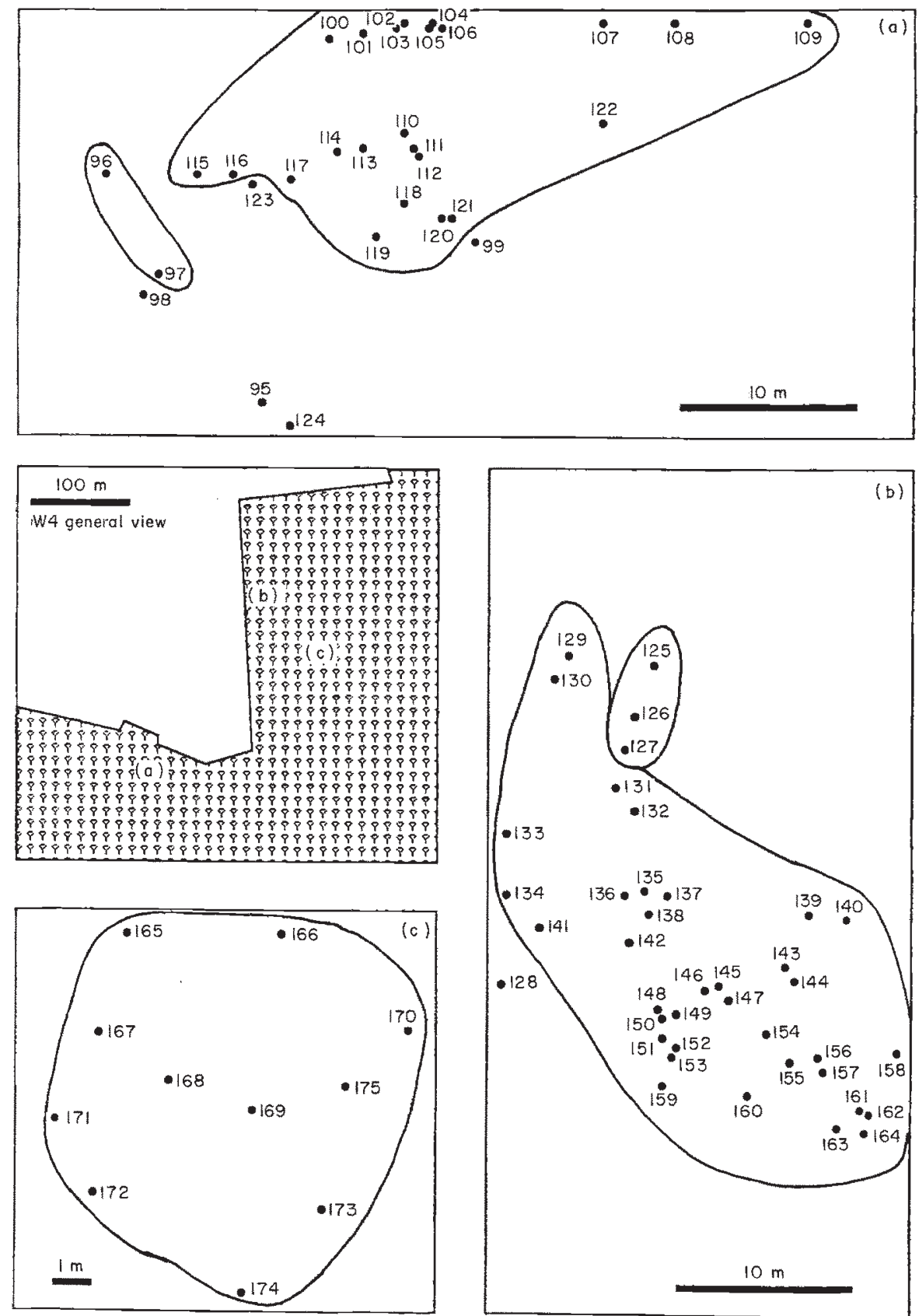

size) was estimated for other groups (groups 5-10, $13-14,20-21,24-25,45-47$ and 59-61). This probability was small for groups including trees 5-10 $(P=0.004$, excluding tree no. 9$), 13-14(P=0.06)$ and 59-60 $(P=0.0001)$. For other groups tested, higher probabilities were obtained $(P>0.1)$. In these cases, the occurrence of vegetative propagation was uncertain. Also, trees no. 9, 20 or 21,24 or 25 and 45 were too far away from their identical clone group $(90-160 \mathrm{~m})$ to be included (Fig. 1). Therefore, 50 rather than 61 individuals were used for the within population differentiation analysis.
In population W2, 7 trees from group A (73-79) had the same multiple-locus genotype, while all trees from the other three groups had different genotypes (Fig. 1). Group A may represent a single clone, but morphological features (data not shown) indicated that this group probably included two subgroups (groups 73-74 and 75-79).

All 24 trees sampled in population W3 had different genotypes.

In population $\mathrm{W} 4,3$ groups of trees were sampled within the stand (Fig. 2). Among these groups, the individuals sampled appeared to represent only a 
few clones. In group A, only 7 genotypes were found among 30 trees ( 23 adjacent trees had the same genotype). In group B, only 3 genotypes were found among 30 trees (one genotype was represented by 26 trees). In group C, all 21 trees had the same genotype.

Table 2 indicated the estimated size of clone groups identified in the 3 populations studied. It is possible that more genotypes may be detected within the same clonal group by testing additional genetic markers.

Table 2 Rough estimations of wild cherry clone size in populations $\mathrm{W} 1, \mathrm{~W} 2$ and $\mathrm{W} 4$

\begin{tabular}{lccc}
\hline Populations & $\begin{array}{l}\text { Clone } \\
\text { groups }\end{array}$ & $\begin{array}{l}\text { Number of } \\
\text { trees }\end{array}$ & $\begin{array}{l}\text { Clone sizes } \\
\left(\mathrm{m}^{2}\right)\end{array}$ \\
\hline W1 & $5-10$ & 6 & 5200 \\
& $13-14$ & 2 & 1700 \\
& $20-21$ & 2 & 2400 \\
& $40-41$ & 2 & 1000 \\
& $46-47$ & 2 & 1400 \\
& $49-51$ & 2 & 1700 \\
W2 & $59-61$ & 2 & 1700 \\
& $73-74$ & 2 & 300 \\
W4 & $75-79$ & 5 & 1000 \\
& $96-97$ & 2 & 25 \\
& $100-122$ & 23 & 600 \\
& $125-127$ & 3 & 20 \\
& $129-164$ & 36 & 600 \\
& $165-175$ & 11 & 100 \\
\hline
\end{tabular}

However, as stated previously, we assumed that all trees belonging to the same group represent one clone produced by suckering. Hence, selected data were chosen for subsequent analysis of variability; only a single tree, from each supposed clone in population $\mathrm{W} 1, \mathrm{~W} 2$ and $\mathrm{W} 4$, was used for the estimation of allelic frequencies.

\section{Within population differentiation}

Little differentiation was observed between subpopulations (mean $F$ st $<7.9$ per cent for $\mathrm{C} 1$ and $<9.2$ per cent for W1) (Table 3). In neither population was a genetic structure due to sexual reproduction detected; the neighbourhood size, as defined by Wright (1951), was probably larger than the chosen population size.

There was no evidence for excess heterozygosity in all loci, except for the SDH-1 locus in population $\mathrm{C} 1$ $\left(\chi^{2}\right.$ significant at the 0.1 level, Table 3$)$. Fis values were generally low among the largest subpopulations. These results suggested an influence of sample size, depending on the groupings.

\section{Genetic differentiation among populations}

Although significant differences in allele frequencies among populations $\mathrm{C} 1$ to $\mathrm{C} 5$ and $\mathrm{W} 1$ to $\mathrm{W} 4$ were detected for three loci (Table 4), estimated values of Gst and Fst were low (Fst mean $=2.7$ per cent for chestnut populations and 4.9 per cent for wild cherry

Table 3 Genetic structure of chestnut $\mathrm{C} 1$ and wild cherry W1 populations

\begin{tabular}{|c|c|c|c|c|c|c|c|c|c|c|c|c|}
\hline \multirow{2}{*}{$\begin{array}{l}\text { Partition } \\
\text { number }\end{array}$} & & \multicolumn{4}{|l|}{ Chestnut } & \multicolumn{7}{|c|}{ Wild cherry } \\
\hline & & PGI-1 & $\mathrm{IDH}-2$ & $\mathrm{SDH}-1$ & mean & SDH-1 & IDH-1 & LAP-1 & MDH-1 & $\mathrm{ACP}-1$ & GOT-1 & mean \\
\hline \multicolumn{13}{|c|}{ Genic structure } \\
\hline \multirow[t]{4}{*}{$\chi^{2}$ test } & 1 & $\mathrm{NC}$ & $\mathrm{NC}$ & $\mathrm{NC}$ & - & $\mathrm{NC}$ & $\mathrm{NC}$ & $\mathrm{NC}$ & $\mathrm{NC}$ & $\mathrm{NC}$ & $\mathrm{NC}$ & - \\
\hline & 2 & $\mathrm{NC}$ & $\mathrm{NC}$ & $\mathrm{NC}$ & - & $\mathrm{NC}$ & $\mathrm{NC}$ & $\mathrm{NC}$ & $\mathrm{NC}$ & $\mathrm{NC}$ & $\mathrm{NC}$ & - \\
\hline & 3 & 0.567 & 0.089 & $9.377^{*}$ & - & 3.30 & 4.20 & 2.90 & 3.70 & $\mathrm{NC}$ & $\mathrm{NC}$ & - \\
\hline & 4 & 0.555 & 0.079 & $9.870^{*}$ & - & 3.60 & 2.80 & 1.10 & 2.00 & 2.0 & 0.10 & - \\
\hline \multicolumn{13}{|c|}{ Genotypic structure } \\
\hline \multicolumn{13}{|c|}{$F$-statistics } \\
\hline \multirow[t]{4}{*}{ Fst } & 1 & 0.083 & 0.113 & 0.043 & 0.079 & 0.114 & 0.049 & 0.056 & 0.059 & 0.153 & 0.040 & 0.080 \\
\hline & 2 & 0.070 & 0.065 & 0.063 & 0.066 & 0.272 & 0.045 & 0.032 & 0.031 & 0.122 & 0.050 & 0.092 \\
\hline & 3 & 0.040 & 0.047 & 0.036 & 0.041 & 0.031 & 0.040 & 0.027 & 0.034 & 0.015 & 0.018 & 0.027 \\
\hline & 4 & 0.023 & 0.026 & 0.020 & 0.023 & 0.034 & 0.027 & 0.011 & 0.019 & 0.019 & 0.001 & 0.018 \\
\hline \multirow[t]{4}{*}{ Fis } & 1 & -0.165 & -0.142 & -0.326 & -0.211 & -0.047 & -0.076 & 0.077 & -0.255 & -0.352 & -0.080 & -0.122 \\
\hline & 2 & -0.135 & -0.055 & -0.332 & -0.174 & 0.031 & -0.073 & 0.088 & -0.201 & -0.298 & -0.075 & -0.088 \\
\hline & 3 & -0.119 & -0.054 & -0.320 & -0.164 & 0.026 & -0.068 & 0.092 & -0.206 & -0.158 & -0.039 & -0.058 \\
\hline & 4 & -0.091 & -0.029 & -0.300 & -0.140 & 0.023 & -0.053 & 0.107 & -0.187 & -0.162 & -0.021 & -0.048 \\
\hline
\end{tabular}

*Significant at the 0.1 level, $\mathrm{NC}=$ non-calculable. 
Table 4 Genetic structure of chestnut (C1-5) and wild cherry (W 1-4) populations (pop)

\begin{tabular}{|c|c|c|c|c|c|c|c|c|c|c|c|c|}
\hline \multicolumn{5}{|l|}{ Chestnut } & \multicolumn{8}{|c|}{ Wild cherry } \\
\hline Pop & PGI-1 & IDH-2 & SDH-1 & mean & Pop & $\mathrm{SDH}-1$ & IDH-1 & LAP-1 & MDH-1 & ACP-1 & GOT-1 & mean \\
\hline \multicolumn{13}{|c|}{ Genic structure } \\
\hline \multicolumn{13}{|c|}{ Allele frequencies } \\
\hline \multirow[t]{3}{*}{$\mathrm{C} 1$} & a 0.423 & 0.829 & 0.301 & - & W1 & 0.227 & 0.527 & 0.609 & 0.282 & 0.874 & 0.836 & - \\
\hline & 0.577 & 0.171 & 0.699 & - & & 0.773 & 0.473 & 0.391 & 0.718 & 0.126 & 0.156 & - \\
\hline & - & - & - & & & 0 & 0 & 0 & 0 & 0 & 0.008 & - \\
\hline \multirow[t]{3}{*}{$\mathrm{C} 2$} & 0.733 & 0.730 & 0.125 & - & W2 & 0.321 & 0.679 & 0.536 & 0.250 & 0.750 & 0.857 & - \\
\hline & 0.267 & 0.027 & 0.875 & - & & 0.679 & 0.321 & 0.464 & 0.075 & 0.179 & 0.143 & - \\
\hline & - & - & - & & & 0 & 0 & 0 & 0 & 0.071 & 0 & - \\
\hline \multirow[t]{2}{*}{$\mathrm{C} 3$} & 0.526 & 0.636 & 0.217 & - & W3 & 0.429 & 0.607 & 0.786 & 0.214 & 0.750 & 0.964 & - \\
\hline & 0.474 & 0.364 & 0.783 & - & & 0.571 & 0.393 & 0.214 & 0.786 & 0.025 & 0.036 & - \\
\hline \multirow[t]{2}{*}{$\mathrm{C} 4$} & 0.458 & 0.819 & 0.454 & - & W4 & 0.577 & 0.923 & 0.962 & - & - & 1.000 & - \\
\hline & 0.542 & 0.181 & 0.546 & - & & 0.423 & 0.077 & 0.038 & - & - & 0 & - \\
\hline \multirow[t]{2}{*}{$\mathrm{C} 5$} & 0.488 & 0.819 & 0.296 & - & & - & - & - & - & - & - & - \\
\hline & b $\quad 0.512$ & 0.181 & 0.704 & - & & - & - & - & - & - & - & - \\
\hline$\chi^{2}$ test & t $23.75^{*}$ & $24.14^{*}$ & $23.31^{*}$ & - & & $13.8^{*}$ & $14.5^{*}$ & $15.9^{*}$ & 0.56 & $\mathrm{NC}$ & $\mathrm{NC}$ & - \\
\hline \\
\hline Fst & 0.023 & 0.035 & \multicolumn{10}{|c|}{$F$-statistics and Gst } \\
\hline Gst & 0.034 & 0.026 & 0.140 & 0.066 & & 0.071 & 0.101 & 0.136 & 0.004 & 0.020 & 0.059 & 0.065 \\
\hline Fit & 0.086 & 0.024 & -0.260 & -0.050 & & 0.063 & 0.033 & 0.220 & 0.175 & -0.102 & 0.067 & 0.018 \\
\hline Fis & 0.064 & -0.010 & -0.289 & -0.078 & & -0.010 & -0.046 & 0.150 & -0.179 & -0.127 & 0.031 & -0.030 \\
\hline
\end{tabular}

*Significant at the 0.1 level, $\mathrm{NC}=$ non-calculable.

Table 5 (a) Calculations of Nei's genetic distances among five chestnut populations (Nei, 1972). (b) Calculations of Nei's genetic distances among four wild cherry populations (Nei, 1972)

\begin{tabular}{lllll}
\hline (a) Populations & C2 & C3 & C4 & C5 \\
\hline C1 & 0.072 & 0.027 & 0.017 & 0.002 \\
C2 & & 0.035 & 0.107 & 0.053 \\
C3 & & & 0.067 & 0.022 \\
C4 & & & & 0.015
\end{tabular}

\begin{tabular}{llll}
\hline (b) & W2 & W3 & W4 \\
\hline W1 & 0.016 & 0.034 & 0.155 \\
W2 & & 0.035 & 0.114 \\
W3 & & & 0.049 \\
\hline
\end{tabular}

populations, Table 4), indicating a limited level of differentiation among the populations.

Nei's genetic distances calculations (Table 5) also suggested that there was little genetic differentiation among the populations. A close genetic relationship existed among C1, C4 and C5, while W4 was slightly more separated from other wild cherry populations
(Table 5), though geographic and genetic distances were never correlated.

\section{Discussion and conclusion}

The isoenzyme loci used to assess chestnut populations appear to be sufficient to allow the attribution of shoots of stumps. In wild cherry populations, the genetically homogeneous groups observed in our study cover a maximum of 0.52 ha but other genetic markers are certainly necessary to estimate precisely the size of the sucker groups. This estimated value is far less than that observed with Populus tremuloides (Cheliak \& Dancik, 1982 ), but is in agreement with observations made on Prunus avium populations which occur in small dispersed clusters. Prunus avium has less suckering ability than Prunus cerasus, a closely related species with no incompatibility system (Crane, 1923). In natural populations of Prunus avium, individuals with a high suckering ability can produce more gametes, but have a higher probability of producing somatic mutations for the gametophytic incompatibility S-locus. Spontaneous and artificially obtained mutations on the S-locus (restoring in this case self-compatibility) have been observed by Lewis \& Crowe (1954). A mutant for 
another allele of the S-series can easily pollinate all of the clusters producing highly homozygous progeny with a supposed depressed fitness. The existence of the incompatibility system could therefore explain the small size of the suckering groups in the populations studied.

The Fis fixation indices calculated for the two species studied suggest that no genetic structure exists within the populations sampled. Negative Fis values found for one locus might be the result of either the selection of closely linked loci or the differing male and female contributions towards seed production, which could favour the survival of heterozygotes.

Lack of differentiation among chestnut populations agrees with the results of studies conducted in Italy on the same species $\left(F_{s t}=6.5\right.$ per cent, Villani et al., $1991)$ and in other species of Fagaceae ( $F s t=4.5$ per cent for Quercus ilex, Yacine \& Lumaret, 1988; 4.2 per cent for Quercus petraea and Quercus robur, Kremer et al., 1991; 5 per cent for Alnus crispa, Bousquet et al., 1987; 6 per cent for Fagus silvatica, Cuguen et al., 1989). The lack of differentiation observed among wild cherry populations is homologous to that found among Ficus carita populations ( $F$ st $=4.3$ per cent, Valizadeh, 1978), which have a similar population distribution and dispersal factors.

According to Loveless \& Hamrick (1984), species whose seeds are dispersed by gravity (chestnut) or by animals (wild cherry) have a mean Gst of 0.446 and 0.332 , respectively, far greater than our calculated values. Nevertheless, it is remarkable how little migration is required to prevent genetic divergence among populations, resulting from random genetic drift. The effect can be seen quantatively by considering the Wright's Island model; the $F$ st at equilibrium is equal to $(1 / 1+4 m N)$, provided that $m$ remains low $(N=$ population size, $m=$ migration rate, Wright, 1951). This equation implies that the $F s t$ decreases as the number of migrants and the population size increase. Indeed, the decrease of Fst with increasing $\mathrm{Nm}$ is extremely rapid. The population size $N$ is high for long-lived, late successional species, such as chestnut and wild cherry. These two species have low pollen production (almost for wild cherry, Pouvreau, personal communication) and, at first glance, limited seed dispersal. The expected low migration rate should therefore lead to a higher level of population variability than in tree species whose pollen and/or seeds are wind dispersed (Loveless \& Hamrick, 1984). However, the migration rate may be higher than expected since human activities may have greatly influenced the migration of seeds produced by edible species (Pigliucci et al., 1990; Frascaria \& Lefranc, 1992) and probably because wild cherry pollen is easily located by insects and able to travel 1 or $2 \mathrm{~km}$. The migration rate $\mathrm{m}$ is therefore not low enough to compensate for the effect of a large population size. In addition, the number of generations completed by European trees is limited, since the species expanded out of refugia following the last glaciation (10,000 years ago) and the $F_{s t}$ has not yet reached equilibrium (Hiebert \& Hamrick, 1982).

\section{Acknowledgements}

We would like to thank Catherine Bourgeois (IDF, Toulouse, France) for access to the different stands, Madeleine Lefranc (University of Paris XI, Orsay, France) for her valuable technical assistance in carrying out electrophoretic analysis and Peng Li and Paul de la Bastide (University of Laval, St-Foy, Canada) for reviewing the manuscript.

\section{References}

BONNEFOI, C. 1984. Etude du polymorphisme enzymatique des populations forestières de châtaignier (Castanea sativa Mill.). Thesis, USTL Montpellier, France.

Bousquet, J., CHELIAK, w. M. AND LAlONDE, M. 1987. Allozyme variability in natural population of green alder (Alnus crispa) in Quebec. Genome, 29, 345-352.

CHELIAK, W. M. AND DANCIK, B. P. 1982. Genic diversity of natural populations of a clone forming tree Populus tremuloides. Can. J. Genet. Cytol., 24, 611-616.

CLAPPER, R. B. 1954. Chestnut breeding, techniques and results. J. Hered., 45, 106-114, 201-208.

CRANE, B. 1923. Report on tests of self-sterility and crossincompatibility in plums, cherries and apples at the John Innes Horticultural Institution II. J. Pomol Hort Science, 3, $67-84$.

CUGUEN, J., MERZEAU, D. AND THIEBAUT, B. 1989. Genetic structure of the European beech stands Fagus silvatica L. Fstatistics and importance of mating system characteristics in their evolution. Heredity, 60, 91-100.

FINESCHI, S., GILLET, E. AND MALvolt, M. E. 1990. Genetics of sweet chestnut (Castanea sativa Mill.). II. Genetic analysis of zymograms of single tree offspring. Silvae Genetica, 39 , $188-193$.

FRASCARIA, N. AND LEFRANC, M. 1992. Le commerce de la châtaigne: un nouvel aspect dans l'étude de la différenciation génétique de populations de châtaigniers (Castanea sativa Mill.) en France. Ann. Sci. Forest., 1, 75-79.

HAMRICK, J. L. 1989. Isozymes and the analysis of genetic structure in plant population. In: Soltis, D. E. and Soltis, P. S. (eds). Isozymes Plant Biology. Discories Press, Portland, pp. 87-105.

HARRIS, H. AND HOPKINSON, D. A. 1976. Handbook of Enzyme Electrophoresis in Human Genetics. North Holland Publishing Company Inc., New York.

HIEBERT, R. D. AND HAMRICK, J. L. 1982. Patterns and levels of genetic variation in great basin bristlecone pine (Pinus longaeva Bailey). Evolution, 37, 302-310. 
KREMER, A., PETIT, P., ZANETTO, A., FOUGERE, V., DUCOUSSO, A., WAGNER, D. AND CHAUVIN, C. 1991. Nuclear and organelle gene diversity in $Q$. robur and $Q$. petraea. In: MullerStarck, G. and Ziette, M. (eds) Genetic Variations in European Forest trees, Saverländer Verlag, 141-166.

LEWIS, D. AND CROWE, L. K. 1954. Study of the incompatibility gene. IV types of mutations in Prunus avium L. Heredity, 8 (3), 357-363.

LOVELESS, M. D. AND HAMRICK, J. L. 1984. Ecological determinants of genetic structure in plant populations. Ann. Rev. Syst., 15, 65-95.

MEINZEL, S. AND MARKET, C. L. 1967. Malate dehydrogenase isozymes of the marine snail, Ilyanassa obsoleta. Arch. Biochem. Biophys., 122, 753-765.

NEI, M. 1972. Genetic distance between populations. Am. Nat., 106, 283-292.

NEI, M. 1973. Analysis of gene diversity in subdivided populations. Proc. Nat. Acad. Sci. U.S.A., 70, 3321-3323.

NEI, M. 1977. $F$-statistics and analysis of gene diversity in subdivided populations. Am. Hum. Genet., 41, 225-233.

NEI, M. 1978. Estimation of average heterozygosity and genetic distance from a small number of individuals. Genetics, 89, 583-590.

NEI, M. 1986. Definition and estimation of fixation indices. Evolution, 40, 643-645.

PigliuCCI, S., BENEDETELli, S. AND Villani, F. 1990. Spatial patterns of genetic variability in Italian chestnut (Castanea sativa Mill.). Can. J. Bot., 9, 1962-1967.

SANTI, F. AND LEMOINE, M. 1991. Genetic markers for Prunus avium L.: inheritance and linkage of isozyme loci. Ann. Soc. For., 47, 131-139.

TANKSLEY, S. D. AND RICK, C. M. 1980. Isozyme gene linkage map of the tomato: applications in genetics and breeding. Theor. Appl. Genet., 57, 161-170.

valizadeH, M. 1978. Aspects génétiques et agronomiques de l'étude de la variabilité des protéines chez les plantes supérieures. Cas du Ficus carita L. Thesis, USTL Montpellier, France.

VILLANI, F., MALVOLTI, M. E., FINESCHI, S, BIMBI, R. AND PACIUCCI, M. 1986. Electrophoretic variations in Castanea sativa $\mathbf{M}$. from Italy. 5th International Congress on Isozymes. Island of Kos, Greece, May 26-29.

Wright, s. 1951. The genetical structure of populations. Ann. Eugen., 15, 323-354.

WRIGHT, s. 1965. The interpretation of population structure by F-statistics with special regard to system of mating. Evolution, 19, 395-420.

YACINE, A. AND LUMARET, R. 1988. Distribution spaciale des génotypes dans une population de chênes verts (Quercus ilex L.), flux génique et régime de reproduction. Genet. Sel. Evol., 20, 181-198. 